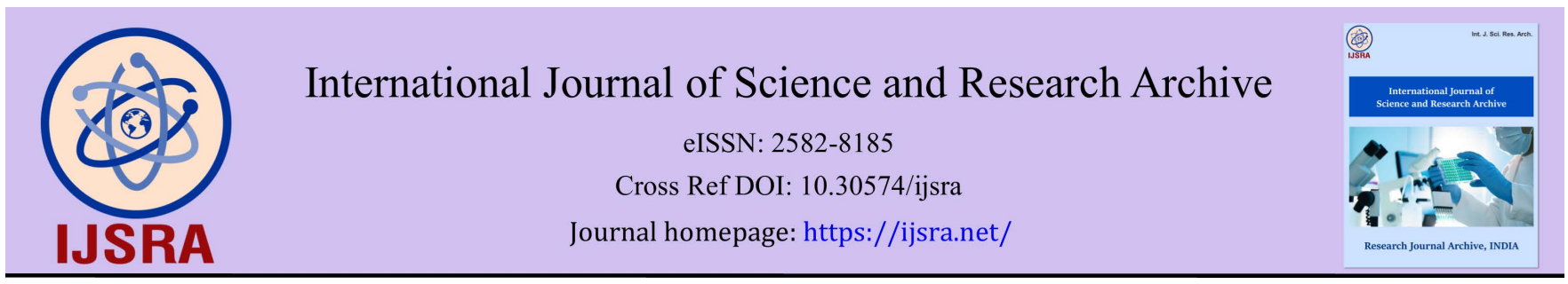

(RESEARCh ARTiCle)

\title{
Growth responses of C3 and C4 crops to soil physico-chemical properties in Rivers State, Nigeria
}

\author{
Odimegwu Vitus Chinonso ${ }^{1}$, Weli Vincent Ezikornwor ${ }^{1, *}$ and Nwagbara Moses Okemini ${ }^{2}$ \\ 1 Department of Geography and Environmental Management, University of Port Harcourt Choba, Port Harcourt, Rivers \\ State, Nigeria. \\ 2 Dept. of Soil Science and Meteorology, Michael Okpara University of Agriculture, Umudike, Nigeria.
}

International Journal of Science and Research Archive, 2021, 03(02), 175-182

Publication history: Received on 29 August 2021; revised on 13 October 2021; accepted on 15 October 2021

Article DOI: https://doi.org/10.30574/ijsra.2021.3.2.0151

\begin{abstract}
This study evaluated the growth responses of C3 and C4 crops to soil physico-chemical properties in Rivers State. The C3 crop refers to Pumpkin and Cucumber while C4 crop refers to Amaranthus in this study. The research work made use of three crops (Pumpkin, Cucumber and Amaranthus in some selected sites in Rivers State and the study was carried out both in the dry and wet seasons. Soil samples were collected from both topsoil $(0-15 \mathrm{~cm})$ and subsoil $(15-30 \mathrm{~cm})$. The crops and soil samples were taken to the laboratory for further analysis. Mean values and standard deviations were used to describe the analysis while analysis of variance (ANOVA), Duncan, and Kruskal Wallis were used to test the hypotheses. All analyses were carried out using Statistical Package for Social Sciences (SPSS) 21.1 Version. Findings showed that sand content in Oyigbo had the highest in the topsoil at 95.37\% while Etche had highest in silt content at $1.87 \%$. For the subsoil, Oyigbo also had the highest sand content at $93.30 \%$ while Ikwerre had the highest clay content at $6.63 \%$ in subsoil. For chemical properties of soil, total organic carbon and magnesium were highest in Oyigbo at $1.91 \%$ and $24.00 \%$ respectively for topsoil while for subsoil potassium was highest in Ikwerre at $8.30 \%$. It was also discovered C3 and C4 crops planted in Oyigbo, Etche and Ikwerre varied from the nutrients standards recommended by USDA (2014). The following nutrients and minerals were considered: energy, carbohydrates, protein, total fat, cholesterol, dietary fiber, vitamins, folates, niacin, pantogenic acid, pyridoxine, riboflavin, thiamin, Electrolytes, sodium, potassium, calcium, iron, magnesium, manganese phosphorus, and zinc. For standards recommended by (USDA 2014), only energy, iron, zinc, manganese, vitamin E, riboflavin, pyridoxine, niacin and pantothenic acid at Oyigbo met the standards, also Riboflavin and iron at Ikwerre met the (USDA 2014) standards while only folates at Etche met the (USDA 2014) standards. The study recommended that the soil nutrients and pH should be improved across the three locations and the acidic nature of both topsoil and subsoil should be improved by neutralizing the soil with lime.
\end{abstract}

Keywords: Soil; Amaranthus; Cucumber; Pumpkin; C3 crops; C4 crops

\section{Introduction}

Soil physico-chemical properties in our environment contribute to the growth of major crops in terms of physiological appearances and nutrients content[1]. Globally, this has become a major concern because when the soil in the environment does not meet up the standards required for such crop the effort of many farmers becomes unfruitful because such crop becomes unsafe for human consumption. Most crops generates their nutrients from the soil and the soil contains both the physical and chemical properties such as: the clay, sand, and the silt while the chemical properties such as the total organic carbon, available potassium, total nitrogen, exchangeable magnesium, exchangeable calcium, TEA are also found in the soil. There is a recommended standard for both C3 and C4 crops as indicated by [2]. [3] posited that there could be an alteration in crops when there is a change in soil's environment. Such alteration can effects the

\footnotetext{
${ }^{*}$ Corresponding author: Weli Vincent Ezikornwor

Department of Geography and Environmental Management, University of Port Harcourt Choba, Port Harcourt, Rivers State, Nigeria. Copyright (C) 2021 Author(s) retain the copyright of this article. This article is published under the terms of the Creative Commons Attribution Liscense 4.0.
} 
following: reduction in sugar and nutrient contents of plants, susceptibility for less development in the leaf, changes in stomata conductance, vegetative growth effect, and plant's variations in several locations. Consumption of crops should be based on recommended standards as seen in several countries where food production is controlled by a Federal Agency like in the case of Nigeria, we have National Agency for Food, Drug, Administration and Control (NAFDAC) the same is also applicable to crops produced in our environment. Because of changes in the climate variation such as evapotranspiration variation, temperature variation, carbon dioxide variation and other greenhouse gases there is need to measure the standards of farm produce before human consumption. This is what this study intends to achieve with USDA 2014 standards on crops produced in three locations in Rivers State. [4] maintained that many crops have lost their nutritional value and mineralogical standard in our environment.

\section{Material and methods}

The study area is Etche, Ikwerre and Oyigbo Local Government aresa of Rivers State in the Niger Delta Region of Nigeria. It is located in the southern region, and has been reported to be one of the major biodiversity hotspots in the world [5]' [6]. The ecosystem is home to several Crops such as Cucumber, Pumpkin and Amaranthus potentials. The three Local governments contains coal plain terrace soil that are recommended by the [7] for C3 and C4 crops. The prominent season for these locations is dry and wet seasons. The wet seasons starts from March to November while the dry seasons starts from November ending to February.The temperature $\left(28 \pm 8{ }^{\circ} \mathrm{C}\right)$ and relative humidity $(50-95 \%)$ is within the estimated range of the area [8]. Primary data were generated during the field data gathering using Atmometer for land level, GPS for location, and soil analyzer for soil, fertometer and crops collected where subjected to lab analysis. Soil samples were taken in various periods like the $43^{\text {rd }}$ period, $49^{\text {th }}$ periods, $56^{\text {th }}$ period, $63^{\text {rd }}$ period and $70^{\text {th }}$ periods in both dry and wet seasons [[9], [10]. Topsoil sample was from $0-15 \mathrm{~cm}$ while subsoil sample was from $15 \mathrm{~cm}-30 \mathrm{~cm}$. The research design adopted in this work has a treatment combinations in Randomized Complete Block Design (RCBD) in factorial Experiment [11].

\subsection{Factors considered where:}

- Factor A (Main Factor): Amaranth, Pumpkin and Cucumber = Crop.

- $\quad$ Factor B (sub-factor i) soil=Environment.

- Factor C (sub-factor ii) Wet and Dry= Season

- Factor D (sub-factor iii) Etche, Oyibo and Ikwerre = Location

NB: Each treatment combination was replicated 3times. This implies that treatment combination $=\mathrm{AxBxCxDxRep}$ $(3 \times 3 \times 2 \times 3 \times 3)=162$.

Table 1 Schematic Presentation of Treatment Combination

\begin{tabular}{|l|c|c|c|}
\hline AxB & Amaranth (Ok) & Pumpkin (Pu) & Cucumber (Cc) \\
\hline Evapotranspiration (Ep) & AmEp & PuEp & CcEp \\
\hline Temperature (Tp) & AmTp & PuTp & CcTp \\
\hline Carbon dioxide (Co) & AmCo & PuCo & CcCo \\
\hline
\end{tabular}

Table $2 \mathrm{ABxC}$

\begin{tabular}{|l|l|l|l|l|l|l|l|l|l|}
\hline ABxC & AmEp & AmTp & AmCo & PuEp & PuTp & PuCo & CcEp & CcTp & CcCo \\
\hline $\begin{array}{c}\text { Ambient } \\
\text { (S1) }\end{array}$ & AmEpS1 & AmTpS1 & AmCoS1 & PuEpS1 & PuTpS1 & PuCoS1 & CcEpS1 & CcTpS1 & CcCoS1 \\
\hline $\begin{array}{c}\text { Chamber } \\
\text { (S2) }\end{array}$ & AmEpS2 & AmTpS2 & AmCoS2 & PuEpS2 & PuTpS2 & PuCoS2 & CcEpS2 & CcTpS2 & CcCoS2 \\
\hline
\end{tabular}


Table 3 ABC x D

\begin{tabular}{|l|l|l|}
\hline Ikwerre (Ik) & OYIBO (OY) & ECTHE (ETC) \\
\hline AmEpAbIk & AmEpAb OY & AmEpAbETC \\
\hline AmTpAbIk & AmTpAb OY & AmTpAbETC \\
\hline AmCoAbIk & AmCoAb OY & AmCoAbETC \\
\hline PuEpAbIk & PuEpAb OY & PuEpAbETC \\
\hline PuTpAbIk & PuTpAb OY & PuTpAbETC \\
\hline PuCoAbIk & PuCoAb OY & PuCoAbETC \\
\hline CcEpAbIk & CcEpAb OY & CcEpAbETC \\
\hline CcTpAbIk & CcTpAb OY & CcTpAbETC \\
\hline CcCoAbIk & CcCoAb OY & CcCoAbETC \\
\hline AmEpChIk & AmEpCh OY & AmEpChETC \\
\hline AmTpChIk & AmTpCh OY & AmTpChETC \\
\hline AmCoChIk & AmCoCh OY & AmCoChETC \\
\hline PuEpChIk & PuEpCh OY & PuEpChETC \\
\hline PuTpChIk & PuTpCh OY & PuTpChETC \\
\hline PuCoChIk & PuCoCh OY & PuCoChETC \\
\hline CcEpChIk & CcEpCh OY & CcEpChETC \\
\hline CcTpChIk & CcTpCh OY & CcTpChETC \\
\hline CcCoChIk & CcCoCh OY & CcCoChETC \\
\hline
\end{tabular}

\subsection{Data that was taken include but not limited to}

- Agronomic data such as plant height, leaf number, 50\% days flowering, maturity and total yield etc [10]

- The soil sample was taken from the surface down to $15 \mathrm{~cm}$ that is from $0-15 \mathrm{~cm}$ and from $15 \mathrm{~cm}$ to $30 \mathrm{~cm}$, it was also sent for laboratory test and the result is stated in chapter four. We took the soil temperature of the three plants starting from $0-2 \mathrm{~cm}$ depth. This is because in planting amaranth and pumpkin, $2 \mathrm{~cm}$ is recommended while that of cucumber $3 \mathrm{~cm}$ [7], [8], [9]

- $\quad$ Land equivalent ratio to plant was also calculated, we have 5 by 5 for cucumber and pumpkin crops per bird and a total of 9 birds in a location. This gives each bird a 25 [11]

- Geo-ecological data such as: evapotranspiration rates, carbon assimilates, temperature reading, physiochemical properties, relative humidity data and day length were also taken for the various locations studied etc [12], [13], [14],[15], [16].

All data were subjected to analysis in a RCBD in factorial experiment where interactions were tested for $A \times B$; $A \times C$, $A$ $\times D, B \times C, B \times D, D \times C, D \times B$ others were on $A B \times C, A B \times D, A C \times D$ and $A B C \times D$, they were subjected to ANOVA and Duncan analysis with error mean square.

\section{Results and discussion}

\subsection{Analysis of physico-chemical properties of soil and the comparison of the nutrients values with [3] Standards.}

The chemical analysis of soil properties shown in Table 4 reveals that $\mathrm{pH}$ in the three locations was weakly acidic ranging from 5.28 in Oyigbo to 6.10 in Etche. The total organic carbon was highest in Oyigbo (1.91\%) while Etche recorded the lowest (1.40\%). Furthermore, the available P varied slightly with the highest in Ikwerre $(13.42 \mathrm{mg} / \mathrm{kg})$ and the least in Etche $(10.73 \mathrm{mg} / \mathrm{kg})$. Among the exchangeable cations, $\mathrm{Mg}$ was the highest which ranged from 1.36 
$\mathrm{mg} / \mathrm{kg}$ in Etche to $29.98 \mathrm{mg} / \mathrm{kg}$ in Etche. Total $\mathrm{N}$ was very low in the study locations ranging from $0.11 \%$ in Etche to $0.17 \%$ in Ikwerre. The total exchangeable acidity was highest in Etche $(1.77 \mathrm{mg} / \mathrm{kg})$ and lowest in Ikwerre $(1.35 \mathrm{mg} / \mathrm{kg})$. This also reflected on why there was poor growth in mostly Pumpkin across the three locations. This result conforms with the findings of [17], [18], [19]. Table 5 explains the chemical properties of soil in Etche, Oyigbo and Ikwerre and from the table, total organic carbon in the topsoil was highest at Oyigbo with $1.91 \%$, available potassium recorded was most in Oyigbo at $13.05 \mathrm{mg}$, the $\mathrm{pH}$ was also more in Etche at 6.10 while total exchangeable acidity was highest in Etche at $1.77 \mathrm{mg}$. While at the subsoil, Total Exchangeable Acidity recorded $2.01 \mathrm{mg}$ in the same Etche and Total Organic carbon was more at Oyigbo with a value of 0.92 . This implies that some chemical properties in the study area did not meet up to the requirement for $\mathrm{C} 3$ and $\mathrm{C} 4$ crops [19].

Table 4 Physical Properties of Soil in the Study Locations

\begin{tabular}{|c|c|c|c|c|}
\hline Soil Parameters & Soil Depth & Etche & Oyigbo & Ikwerre \\
\hline Sand (\%) & \multirow[t]{3}{*}{ Topsoil } & $94.97 \pm 1.3$ & $95.37 \pm 1.5$ & $93.93 \pm 1.3$ \\
\hline Silt (\%) & & $1.87 \pm 0.8$ & $1.5 \pm 0.9$ & $1.67 \pm 0.3$ \\
\hline Clay (\%) & & $3.17 \pm 1.4$ & $3.13 \pm 0.6$ & $4.40 \pm 1.0$ \\
\hline Sand (\%) & \multirow[t]{3}{*}{ Subsoil } & $91.70 \pm 1.8$ & $93.30 \pm 1.4$ & $91.50 \pm 1.8$ \\
\hline Silt (\%) & & $2.13 \pm 0.8$ & $2.07 \pm 0.4$ & $1.87 \pm 0.4$ \\
\hline Clay (\%) & & $6.17 \pm 2.2$ & $4.70 \pm 1.0$ & $6.63 \pm 2.2$ \\
\hline
\end{tabular}

Table 5 Chemical properties of soil in the study locations

\begin{tabular}{|c|c|c|c|c|}
\hline Soil Parameters & Soil Depth & Etche & Oyigbo & Ikwerre \\
\hline $\mathrm{Ph}$ & \multirow[t]{9}{*}{ Topsoil } & $6.10 \pm 0.2$ & $5.28 \pm 0.3$ & $5.60 \pm 0.3$ \\
\hline Total Organic Carbon (\%) & & $1.40 \pm 0.2$ & $1.91 \pm 0.2$ & $1.71 \pm 0.5$ \\
\hline Avail P (mg/kg) & & $10.73 \pm 0.4$ & $13.05 \pm 2.9$ & $13.42 \pm 2.3$ \\
\hline Total N (\%) & & $0.11 \pm 0.1$ & $0.12 \pm 0.1$ & $0.17 \pm 0.1$ \\
\hline Ex. Na (mg/kg) & & $0.95 \pm 0.1$ & $1.07 \pm 0.2$ & $1.00 \pm 0.1$ \\
\hline Ex. K (mg/kg) & & $1.03 \pm 0.2$ & $0.92 \pm 0.1$ & $0.98 \pm 0.4$ \\
\hline Ex. $M g(m g / k g)$ & & $29.98 \pm 5.0$ & $24.00 \pm 3.9$ & $1.36 \pm 0.8$ \\
\hline Ex. Ca (mg/kg) & & $0.63 \pm 0.1$ & $0.77 \pm 0.1$ & $0.82 \pm 0.1$ \\
\hline Total Exchangeable Acidity (mg/kg) & & $1.77 \pm 0.3$ & $1.75 \pm 0.2$ & $1.35 \pm 0.1$ \\
\hline $\mathrm{pH}$ & \multirow[t]{9}{*}{ Subsoil } & $5.57 \pm 0.2$ & $5.27 \pm 0.4$ & $5.37 \pm 0.1$ \\
\hline Total Organic Carbon (\%) & & $0.66 \pm 0.1$ & $0.92 \pm 0.3$ & $0.79 \pm 0.1$ \\
\hline Avail P (mg/kg) & & $7.29 \pm 0.7$ & $7.77 \pm 1.5$ & $8.30 \pm 0.8$ \\
\hline Total N (\%) & & $0.05 \pm 0.1$ & $0.06 \pm 0.1$ & $0.11 \pm 0.1$ \\
\hline Ex. Na (mg/kg) & & $0.85 \pm 0.3$ & $1.05 \pm 0.5$ & $1.10 \pm 0.3$ \\
\hline Ex. K (mg/kg) & & $0.97 \pm 0.2$ & $0.96 \pm 0.2$ & $1.22 \pm 0.4$ \\
\hline Ex. Mg (mg/kg) & & $0.97 \pm 0.3$ & $0.82 \pm 0.1$ & $1.05 \pm 0.3$ \\
\hline Ex. Ca (mg/kg) & & $0.73 \pm 0.1$ & $0.74 \pm 0.1$ & $0.70 \pm 0.2$ \\
\hline Total Exchangeable Acidity (mg/kg) & & $2.01 \pm 0.2$ & $1.56 \pm 0.4$ & $1.26 \pm 0.3$ \\
\hline
\end{tabular}


Table 6 General Physical Properties of Soil

\begin{tabular}{|l|c|c|}
\hline Soil Parameters & Topsoil (0-15cm) & Subsoil (15-30cm) \\
\hline Sand (\%) & $94.76 \pm 1.3$ & $92.17 \pm 1.7$ \\
\hline Silt (\%) & $1.68 \pm 0.6$ & $2.02 \pm 0.5$ \\
\hline Clay (\%) & $3.57 \pm 1.1$ & $5.83 \pm 1.9$ \\
\hline
\end{tabular}

Table 7 General Chemical Properties of Soil

\begin{tabular}{|l|c|c|}
\hline Soil Parameters & Topsoil (0-15cm) & Subsoil (15-30cm) \\
\hline $\mathrm{pH}$ & $5.66 \pm 0.4$ & $5.40 \pm 0.3$ \\
\hline Total Organic Carbon (\%) & $1.67 \pm 0.4$ & $0.79 \pm 0.3$ \\
\hline Avail P (mg/kg) & $12.40 \pm 2.2$ & $7.79 \pm 1.0$ \\
\hline Total N (\%) & $0.13 \pm 0.1$ & $0.07 \pm 0.1$ \\
\hline Ex. $\mathrm{Na}(\mathrm{mg} / \mathrm{kg})$ & $1.00 \pm 0.2$ & $1.00 \pm 0.3$ \\
\hline Ex. $\mathrm{K}(\mathrm{mg} / \mathrm{kg})$ & $0.98 \pm 0.2$ & $1.05 \pm 0.3$ \\
\hline Ex. Mg (mg/kg) & $18.45 \pm 4.6$ & $0.95 \pm 0.3$ \\
\hline Ex. Ca $(\mathrm{mg} / \mathrm{kg})$ & $0.74 \pm 0.1$ & $0.73 \pm 0.1$ \\
\hline TEA $(\mathrm{mg} / \mathrm{kg})$ & $1.62 \pm 0.3$ & $1.61 \pm 0.4$ \\
\hline
\end{tabular}

\subsection{The measurements of nutrients and minerals Contents in Amaranthus, Pumpkin and Cucumber with [2] Standards}

Table 8 shows the comparison between the nutrients and mineral values obtained in the study area with that of the [2]. From the table below, energy (kcal) recommended by USDA was $12 \mathrm{kcal}$ while none of the locations had up to that value, the same applied in carbon hydrates, protein, total fat, dietary fiber in Nutrients alone. In vitamin, the three locations met the standards for Folates $(\mu \mathrm{g})$, vitamin $\mathrm{E}$, while the rest did not, in minerals only manganese and zinc in Oyigbo met the standards while the rest did not. For electrolyte, sodium and potassium did not meet the required standards. This by implication means that cucumber, pumpkin and Amaranthus crops planted in these areas should be carefully consumed because of the less nutrients, minerals and electrolytes contents in them.

Table 8 Average Nutrients, Vitamins, Electrolytes and Mineral Contents in Cucumber, Pumpkin and Amaranthus in the Study Locations in the Wet Season

\begin{tabular}{|l|c|c|c|c|}
\hline Parameters & Etche & Ikwerre & Oyigbo & USDA \\
\hline Nutrients & 8 & 15 & 21 & 12 \\
\hline Energy (Kcal) & 0.16 & 0.18 & 1.23 & 2.16 \\
\hline Carbohydrates (g) & 0.27 & 0.57 & 0.2 & 0.59 \\
\hline Protein (g) & 0 & 0 & 0 & 0.16 \\
\hline Total Fat (g) & 0 & 0 & 0 & 0 \\
\hline Cholesterol (mg) & 0.3 & 0.2 & 0.6 & 0.7 \\
\hline Dietary Fiber (g) & & & & \\
\hline Vitamins & 14 & 17 & 19 & 14 \\
\hline Folates ( $\mu$ g) & 0.037 & 0.2 & 0.03 & 0.037 \\
\hline Niacin (mg) & 0.27 & 0.38 & 0.27 & 0.259 \\
\hline Pantothenic acid (mg)
\end{tabular}




\begin{tabular}{|c|c|c|c|c|}
\hline Pyridoxine (mg) & 0.034 & 0.4 & 0.07 & 0.051 \\
\hline Riboflavin (mg) & 0.01 & 0.1 & 0.05 & 0.025 \\
\hline Thiamin (mg) & 0.23 & 0.34 & 0.26 & 0.031 \\
\hline Vitamin A (IU) & 4 & 3 & 2 & 12 \\
\hline Vitamin C (mg) & 1.2 & 1.4 & 1.2 & 3.2 \\
\hline Vitamin E (mg) & 0.03 & 0.03 & 0.03 & 0.03 \\
\hline Vitamin $\mathrm{K}(\mu \mathrm{g})$ & 3.1 & 2.0 & 2.1 & 7.2 \\
\hline \multicolumn{5}{|l|}{ Electrolytes } \\
\hline Sodium (mg) & 1 & 1.1 & 1.01 & 2 \\
\hline Potassium (mg) & 11 & 11.3 & 1.7 & 136 \\
\hline \multicolumn{5}{|l|}{ Mineralss } \\
\hline Calcium (mg) & 3.2 & 4.5 & 3.3 & 14 \\
\hline Iron (mg) & 0.11 & 1.11 & 1.10 & 0.22 \\
\hline Magnesium (mg) & 4 & 5 & 3 & 12 \\
\hline Manganese (mg) & 0.43 & 1.043 & 2.053 & 0.079 \\
\hline Phosphorus (mg) & 11 & 11.1 & 8.9 & 21 \\
\hline Zinc (mg) & 0.12 & 0.11 & 1.03 & 0.17 \\
\hline
\end{tabular}

Table 9 Average Nutrient content in Cucumber, Pumpkin and Amaranthus in Dry Season in Etche, Ikwerre and Oyigbo LGAs

\begin{tabular}{|c|c|c|c|c|}
\hline Parameters & Etche & Ikwerre & Oyigbo & USDA \\
\hline \multicolumn{5}{|l|}{ Nutrients } \\
\hline Energy (Kcal) & 2 & 9 & 14 & 12 \\
\hline Carbohydrates (g) & 0.6 & 0.11 & 0.2 & 2.16 \\
\hline Protein $(\mathrm{g})$ & 0.1 & 0.2 & 1.2 & 0.59 \\
\hline Total Fat (g) & 0 & 0 & 0 & 0.16 \\
\hline Cholesterol (mg) & 0 & 0 & 0 & 0.69 \\
\hline Dietary Fiber (g) & 0.3 & 0.1 & 0.3 & 0.7 \\
\hline \multicolumn{5}{|l|}{ Vitamins } \\
\hline Folates $(\mu \mathrm{g})$ & 14 & 12 & 12 & 14 \\
\hline Niacin (mg) & 0.037 & 0.02 & 0.2 & 0.037 \\
\hline Pantothenic acid (mg) & 0.27 & 0.24 & 0.17 & 0.259 \\
\hline Pyridoxine (mg) & 0.034 & 0.04 & 1.34 & 0.051 \\
\hline Riboflavin (mg) & 0.01 & 1.01 & 0.4 & 0.025 \\
\hline Thiamin (mg) & 0.23 & 0.24 & 0.12 & 0.031 \\
\hline Vitamin A (IU) & 4 & 1 & 1 & 12 \\
\hline Vitamin C (mg) & 1.2 & 0.1 & 0.1 & 3.2 \\
\hline Vitamin E (mg) & 0.03 & 0.03 & 0.02 & 0.03 \\
\hline Vitamin $\mathrm{K}(\mu \mathrm{g})$ & 3.1 & 1.0 & 1.2 & 7.2 \\
\hline \multicolumn{5}{|l|}{ Electrolytes } \\
\hline Sodium (mg) & 1 & 0.1 & 1.01 & 2 \\
\hline Potassium (mg) & 11 & 9.2 & 0.2 & 136 \\
\hline \multicolumn{5}{|l|}{ Minerals } \\
\hline Calcium (mg) & 3.2 & 2.1 & 2.1 & 14 \\
\hline
\end{tabular}




\begin{tabular}{|c|c|c|c|c|}
\hline Iron (mg) & 0.11 & 1.0 & 0.20 & 0.22 \\
\hline Magnesium(mg) & 4 & 2 & 1.2 & 12 \\
\hline Manganese (mg) & 0.043 & 0.043 & 1.3 & 0.079 \\
\hline Phosphorus (mg) & 11 & 2 & 4.6 & 21 \\
\hline Zinc (mg) & 0.12 & 1.12 & 0.1 & 0.17 \\
\hline \multicolumn{5}{|l|}{ Phyto-nutrients } \\
\hline Carotene- $\beta(\mu \mathrm{g})$ & 0 & 0 & 0 & 31 \\
\hline Crypto-xanthin- $\beta(\mu \mathrm{g})$ & 0 & 0 & 0 & 18 \\
\hline Lutein-zeaxanthin $(\mu \mathrm{g})$ & 0 & 0 & 0 & 16 \\
\hline Water $(\mathrm{g})$ & 47 & 15.8 & 0 & 96.73 \\
\hline Energy (Kcal) & 0 & 0 & 0 & 12 \\
\hline Protein $(\mathrm{g})$ & 0 & 0 & 0 & 0.59 \\
\hline Total lipid (fat) (g) & 0 & 0 & 0 & 0.16 \\
\hline Carbon hydrate by difference(g) & 0 & 0 & 0 & 2.16 \\
\hline Fiber, total dietary $(\mathrm{g})$ & 0 & 0 & 0 & 0.7 \\
\hline Sugars, total including NLEA(g) & 0 & 0 & 0 & 1.38 \\
\hline Calcium (mg) & 0 & 0 & 0 & 14 \\
\hline Iron (mg) & 0 & 0 & 0 & 0.22 \\
\hline Magnesium (mg) & 0 & 0 & 0 & 12 \\
\hline Phosphorus (mg) & 0 & 0 & 0 & 21 \\
\hline Potassium (mg) & 0 & 0 & 0 & 136 \\
\hline
\end{tabular}

\section{Conclusion}

This study evaluated the growth responses of C3 and C4 crops to Soil Physio-Chemical Properties in Rivers State. A C3 crop in this study refers to Cucumber and Pumpkin while the C4 crop refers to Amaranthus. Methodologically, three locations were selected in Rivers State namely: Etche, Oyigbo and Ikwerre this is because the three locations have the coal plain terrace soil as recommended by [7] in planting Cucumber, Pumpkin and Amaranthus. Agronomic data such as: plant height, leaf number, $50 \%$ days flowering, maturity, total yields and geo-ecological data such as: evapotranspiration rates, carbon assimilates, temperature reading were collected. The study made use of Randomized Complete Block Design in factorial experiment. From the discussions of findings, it was revealed Pumpkin, Cucumber and Amaranthus responded to soil physico-chemical variations at the $43^{\text {rd }}, 49^{\text {th }}, 56^{\text {th }}, 63^{\text {rd }}$ and $70^{\text {th }}$ periods of observations in the field. This variation in soil physico-chemical properties also affected the crops Nutrients and mineral such as: Vitamin A, Vitamin K, Energy, Phosphorous, Protein, Height, Leaf, D/Fiber, and Cholesterol. Some of the nutrients and minerals obtained from the study did not meet up the standards recommended by [2]. Such minerals and nutrients are carbohydrates, protein, total fats, cholesterol, Vitamin A, Vitamin C, Vitamin K, Potassium, Calcium, Magnesium and Phosphorus.

\section{Compliance with ethical standards}

\section{Acknowledgments}

The authors wish to acknowledge the support of the local inhabitants of the study areas in River State specifically in Etche, Oyigbo and Ikwerre Local Government areas. We also extend our appreciation to all the field assistants hired throughout the period of this study

\section{Disclosure of conflict of interest}

There is no conflict of interest among the authors concerning this paper. 


\section{References}

[1] Barlow KM, BP Christy. Simulating the impact of extreme heat and forest events on wheat crop production: a review, Field crops Res. 2015; 171: 109-119.

[2] The U.S. Department of Agriculture (USDA) The effects of Climate Change on Agriculture, Land Resources, Water Resources and Biodiversity in the United States; New York. 2014

[3] Sage, N. T 7 Kubien R.T. Photosynthesis at low Temperature: A study using Transgenic Plants with Reduced Amounts of Rubisco. Toronto: Wilco S. Publishing. 2003

[4] Mabel TN. Conditions of man and its Environment: Copenhagen Heen: Stunted Press 243618. Tere Mass. 2011.

[5] Izah SC, Aigberua AO. Assessment of Microbial Quality of Cassava Mill Effluents Contaminated Soil in a Rural Community in the Niger Delta, Nigeria. EC Microbiology. 2017;13(4):132-140.

[6] Izah SC, Bassey SE, Ohimain EI. Impacts of Cassava mill effleunts in Nigeria. Journal of Plant and Animal Ecology. 2018;1(1):14-42.

[7] FAO. FAOSTAT. Food and Agriculture Organization of the United Nations. 2011

[8] Izah SC, Ohimain EI. Microbiological quality of palm oil used in Nigeria: Health impacts perspective. Point Journal of Botany and Microbiology Research. 2016;2(1):037-045.

[9] Izah SC, Angaye CN, Aigberua AO. Uncontrolled bush burning in the Niger Delta region of Nigeria: potential causes and impacts on biodiversity. International Journal of Molecular Ecology and Conservation. 2017;7(1):1-15.

[10] Beppu K, Ikeda T. Effect of high temperature exposure time during flower bud formation on the occurrence of double pistils in Satohnishik sweet cherry.Satohnishik; Double Publishing. 2011.

[11] Bunce JA. Carbon Dioxide effect on stomatal responses to the Environment and water use by crops under field conditions. New Orleans; oecologia house centre. 2013.

[12] Dupuis L, Dumas C. Influence of Temperature Stress on invitro Fertilization and heat shock protein Synthesis in maize (zea mays L.) reproductive system, Plant Physio. Bucharist- Siatel Press. 1990.

[13] Egwuogu CC, Okeke UH, Alaga AT, Eguaroje EO. Geo-Spatial Assessment of Changes in Vegetation in the Southern Delta Areas of Rivers State, Nigeria. International Journal of Trend in Research and Development. 3(6): 408-415.

[14] Gilbert P. The Carbon dioxide Theory of Climate Change Baltimore, mds; John Hoplans University. 1955.

[15] Gosh SCA, Koh I. Effects of temperature at different growth stages on non-structural carbohydrate, nitrate reduce case activity and yield of Potatos. US. Study house. 2011.

[16] Hatfield et al. Evaluation of an electronic foliometre to measure leave area in Corn and Soybean. Agro.J. 1976; 68: 434-436.

[17] Hatfield JL, KJ Boote. The effects of Climate Change on Agriculture, Land Resources, Water Resources and Biodiversity in the United States; New York. 2008.

[18] Marco TS. Understanding climate change through plants: yield Store 43627 limited. YkC its processes and cultivation. London: Hartsfield Press Ltd. 2012.

[19] Sage NT, 7 Kubien RT. Photosynthesis at low Temperature: A study using Transgenic Plants with Reduced Amounts of Rubisco. Toronto: Wilco S. Publishing. 2003 